\title{
Bibliografia historii nauki w Instytucie Historii Nauki PAN
}

\section{History of Science Bibliography at the Institute for the History of Science of the Polish Academy of Sciences}

The article presents the history of preparing the history of science bibliography at the Institute for the History of Science of the Polish Academy of Sciences. The purpose of creating such a bibliography is to facilitate scholars' access to publications in this field of knowledge.

The beginnings of this bibliography date back to 1966, but the official date of its creation should be 1971. The article recalls its authors and describes the thematic scope from its inception to 2008 when the publication was discontinued for financial reasons.

In 2018 , the publishing of the history of science bibliography was resumed.

Keywords: bibliography, history of science, Polish science

Słowa kluczowe: bibliografia, historia nauki, nauka polska

Wstęp - znaczenie historii nauki, oświaty i techniki dla kultury

Historia nauki, oświaty i techniki ze względu na swoją interdyscyplinarność stanowi wiedzę źródłową dla pytań o naturę człowieka i jego wizję świata. Badania z tego zakresu zbierają w całość m.in. studia nad historią techniki, medycyny, biologii, botaniki, idei, edukacji, filozofii nauki, socjologii wiedzy, antropologii wiedzy, polityki i organizacji nauki, instytucji naukowych, organizacji naukowych czy muzealnictwa naukowego. Historia nauki jest więc bardzo specyficznym przedmiotem badań: zajmuje się wszystkimi dziedzinami wiedzy w ich historycznych uwarunkowaniach. We współczesnym świecie nauka w jej historycznym rozwoju decyduje o postawach społecznych i wyobrażeniach światopoglądowych. Historia nauki jest głęboko związana z innymi działami kultury, w tym techniką, filozofią, sztuką, oświatą oraz religią, z którymi nie jest jednak tożsama. Tego rodzaju wiedza jest niezmiernie ważna tak dla adeptów nauk ścisłych, jak i nauk humanistycznych. 
Z perspektywy środowisk związanych z Międzynarodową Unią Historii i Filozofii Nauki dyscyplina ta postrzegana jest jako naturalny pomost pomiędzy naukami ścisłymi i przyrodniczymi, naukami społecznymi oraz humanistyką jako czynnik promujący rozumienie roli nauki w przeszłości, w czasach obecnych oraz przyszłości. Dlatego też historia nauki i techniki jako specyficzna dyscyplina badawcza jest od ponad 100 lat rozwijana w Polsce i na świecie, a wagę badań w tym zakresie podkreślają liczne międzynarodowe stowarzyszenia.

Dla zaakcentowania niezaprzeczalnej wartości tej dyscypliny warto w tym miejscu przytoczyć słowa prof. Henryka Samsonowicza, zamieszczone we Wstępie do Księgi jubileuszowej, wydanej z okazji 50-lecia istnienia Instytutu Historii Nauki PAN:

Istnienie każdej wspólnoty uwarunkowane jest jej pamięcią. Dla wspólnoty Polskiej Akademii Nauk jej przechowywanie jest ważne z wielu przyczyn: pozwala na przeprowadzenie bilansu dokonań, na uzyskiwanie wiedzy o krętych ścieżkach poznania, niekiedy na wdrażanie pomysłów dojrzałych do realizacji. Dziedzina historii nauki, której jubileusz właśnie obchodzimy, jest pamięcią całego środowiska naukowego. Nie dotyczy ona jedynie osiągnięć badawczych poszczególnych dyscyplin. Jest kroniką ludzkich poszukiwań prawdy, rejestracją osiągnięć i błędów, zapisem meandrów myśli badawczej. [...] Instytut nie jest - i nie powinien być przypisany tematyką swej działalności wyłącznie do nauk społecznych. Jak żaden inny w Akademii Nauk, stanowić powinien ośrodek działający ponad granicami dzielącymi dyscypliny naukowe. Jest, jako jedyna placówka w naszym środowisku, przykładem świadczącym, że nauka jest jedna i niepodzielna, że poszukiwanie prawdy o świecie stanowi cel wspólny dla wszystkich badaczy ${ }^{1}$.

Powyższa wypowiedź dobrze koresponduje z treścią artykułu wstępnego do jednego z pierwszych numerów „Kwartalnika Historii Nauki i Techniki”, czasopisma wydawanego nieprzerwanie od 1956 r. (do 1960 przez Komitet Historii Nauki PAN; od 1961 przez Zakład Historii Nauki i Techniki PAN²):

Geneza historii nauki wiąże się ściśle ze wzrostem zainteresowania wiedzą, jako jednym z decydujących czynników współczesnego życia. Znajomość dziejów pewnych gałęzi wiedzy sprzyja - jak się okazało - osiągnięciu właściwego poziomu prowadzonych współcześnie poszukiwań naukowych. Pełny obraz etapów rozwojowych danej gałęzi nauki sprawia, że uczony może wytworzyć sobie należyty pogląd na całokształt zagadnienia i skierować swe wysiłki badawcze na właściwą drogę i we właściwym kierunku.

Historia nauki nie może oczywiście ograniczać się do opisu faktów, lecz musi dążyć do ich wyjaśnienia i ustalenia praw rządzących zjawiskami, zachodzącymi w dzie-

1 H. Samsonowicz, [Słowo wstępne], [w:] Instytut Historii Nauki Polskiej Akademii Nauk w latach 1953-2003, red. K. Bartnicka, Warszawa 2004, s. 9.

2 W 1953 r. na posiedzeniu Sekretariatu Naukowego Prezydium PAN przyjęto uchwałę dotyczącą powstania Zakładu Historii Nauki PAN (Uchwała 155a/53 z 10 listopada 1953 r.); w 1958 przekształcono go w Zakład Historii Nauki i Techniki PAN (Uchwała Prezydium PAN nr 15/58 z 22 kwietnia 1958 r.); w 1977 r. zmieniono nazwę na Instytut Historii Nauki Oświaty i Techniki PAN (Uchwała nr 4/77 Prezydium PAN z 24 lutego 1977 r.); w 1994 r. skrócono nazwę na Instytut Historii Nauki PAN (Decyzja nr 2/94 sekretarza naukowego PAN z 5 stycznia 1994 r.); w 2011 r. do nazwy Instytutu dodano: im. Ludwika i Aleksandra Birkenmajerów (Uchwała nr 25/2011 Prezydium PAN z dnia 17 maja 2011 r.). 
jach nauki. Nie wystarczy zreferować to, co mówił pewien myśliciel lub co odkrył pewien uczony, lecz trzeba wytłumaczyć, d la czego tak mówił i dlaczego dokonał pewnego odkrycia. Odpowiedź na tak postawione pytanie będzie możliwa tylko wówczas, gdy historia nauki zostanie związana z historią kultury, pojętą jako dzieje całokształtu przemian umysłowych i artystycznych narodu, połączonych z jego życiem gospodarczym i politycznym ${ }^{3}$.

\section{Bibliografia historii nauki}

W świetle zacytowanych we wstępie opinii staje się jasna decyzja, aby w „Kwartalniku Historii Nauki i Techniki" publikować informacje o aktualnie ukazującym się piśmiennictwie z szeroko pojętej historii nauki. Na tę decyzję niewątpliwie miał też wpływ pozytywny oddźwięk i ogromne zainteresowanie historyków nauki opublikowaną w 1966 r. Bibliografią zawartości tomów I-X 1956-1965 „Kwartalnika”“4 I tak, w 1970 r. na zebraniu Komitetu Redakcyjnego czasopisma jego ówczesny sekretarz naukowy Jerzy Róziewicz przedstawił projekt wydawania (jako oddzielnej wkładki) bieżącej bibliografii z zakresu historii nauki i techniki. Projekt ten został zaakceptowany. Róziewicz przystąpił do opracowania ogólnych zasad redagowania i wydawania bibliografii oraz do kompletowania zespołu autorskiego. Ogromnej pomocy w tym zakresie udzieliła Dyrekcja Biblioteki PAN w Warszawie delegując do sporządzania tej bibliografii swoje pracownice ${ }^{5}$. W założeniu Bibliografia Bieżąca Historii Nauki i Techniki miała mieć charakter szybkiej, aktualnej informacji o piśmiennictwie z powyższej dziedziny - w zasadzie o drukach krajowych ukazujących się począwszy od dnia I stycznia 1971 r. - a przeznaczona być przede wszystkim dla historyków nauki i techniki. Wprawdzie prace odnoszące się do tego tematu były rejestrowane w tym czasie w wielu wydawnictwach bibliograficznych, zarówno ogólnych (Przewodnik Bibliograficzny, Bibliografia Zawartości Czasopism) jak i specjalistycznych (Bibliografia Historii Polskiej, Polska Bibliografia Lekarska, Polska Bibliografia Prawnicza i inne), lecz wydawnictwa te, opierając się na innych kryteriach doboru materiału, nie preferowały historii nauki i techniki i nie wyodrębniały jej jako oddzielnej dziedziny. Dlatego też korzystanie $z$ tych bibliografii dla historyka nauki i techniki było zbyt czasochłonne z powodu rozproszenia potrzebnych mu informacji, a często też niecelowe z powodu ich opóźnienia ${ }^{6}$. Do dnia dzisiejszego korzystanie z wyżej wymienionych bibliografii jest niezmiernie żmudne i pracochłonne, pomimo ich umiejscowienia w Internecie, ponieważ żadna z nich nie uwzględnia w słowach kluczowych terminu historia nauki.

3 W. Voisé, O zadaniach i metodzie historii nauk społecznych, „Kwartalnik Historii Nauki i Techniki” t. 3, 1958, nr 1, s. 9-10.

4 Bibliografia zawartości tomów „Kwartalnika” była publikowana trzykrotnie: zawartość roczników 1-10 za lata 1956-1965 (zestawił J. Róziewicz), 11-20 za lata 1966-1975 (zestawił J. Róziewicz, 1975 r.) i 21-35 za lata 1976-1990 (zestawił A. Matuszewski, 2002 r.).

5 Bibliografia bieżąca historii nauki i techniki. Indeksy za lata 1971-1980. Indeks autorów i współpracowników. Indeks przedmiotowy osób i instytucji, zestawiły M. Jedlińska, I. Lenart, B. Michalczyk, red. M. Kinowska, J. Róziewicz, Warszawa 1983, s. 154. Bibliografia jest dodatkowym zeszytem dołączonym do „Kwartalnika Historii Nauki i Techniki" t. 28, 1983, nr 3-4.

6 Bibliografia bieżąca historii nauki i techniki. Zeszyt 1. Dodatek do numeru 3/1971 "Kwartalnika Historii Nauki i Techniki”, "Kwartalnik Historii Nauki i Techniki” t. 16, 1971, nr 3, s. 1. 
Bibliografią, która uwzględniała również (wraz z innymi dziedzinami wiedzy) historię nauki i techniki, była opracowywana od 1963 r. Polska Bibliografia Naukoznawstwa i Technoznawstwa7 przygotowywana przez pracowników Biblioteki Polskiej Akademii Nauk (dziś nieistniejącej) w Warszawie ${ }^{8}$. W Bibliografii tej dział historii nauki i techniki był rozbudowany ze względu na dotychczasowy brak informacji bibliograficznej z tego zakresu. Jednakże w 1975 r. jej redakcja zdecydowałą o nieuwzględnianiu publikacji z zakresu historii nauki począwszy od tomu 5. Jak napisała Maria Dembowska, decyzję umotywowano tym, że od 1971 r. historia nauki i techniki posiada swoją własną bibliografię bieżącą, a także względami merytorycznymi: „historia nauki jest już w pełni ukształtowaną, samodzielną dyscypliną wyodrębnioną zarówno pod względem merytorycznym, jak i organizacyjnym (instytucjonalnym)" .

I tak od numeru 3/1971 „Kwartalnika Historii Nauki i Techniki” rozpoczęto wydawanie Bibliografii bieżącej historii nauki i techniki, które zakończyło się w 2007 r. Do połowy 2007 r. ukazało się 129 zeszytów. W numerach 3-4/2007 i 1/2008 „Kwartalnika” opublikowano notatkę informującą, że Bibliografia ukaże się w następnym numerze. Jednak to już nie nastąpiło z powodów finansowych.

Pierwszymi autorkami Bibliografii były: Aldona Gawecka i Jadwiga Majewska-Tronowicz (obie zatrudnione w Bibliotece PAN w Warszawie), a organizacją konsultacji naukowej zajął się Bohdan Jaczewski, pracownik Zakładu Historii Nauki i Techniki PAN (jednak tylko pierwszego numeru).

Od numeru 2 Bibliografii ${ }^{10}$ do koordynacji prac nad bibliografią Dyrekcja Zakładu skierowała Małgorzatę Kinowską, z domu Trzcińską (od 1969 r. pracownik, a od 1985 r. kierowniczka Biblioteki). Ostatnim współtworzonym przez nią zeszytem był dodatek nr 81 do $\mathrm{nr}$ 2/92.

Nad kolejnymi numerami pracowano w składzie: Aldona Gawecka (w latach 1971-1973, zeszyty l-8, dodatek do nr 3/71-2/73), Jadwiga Majewska-Tronowicz (1971 - marzec 1980, zeszyty I-37, dodatek do nr 3/71-3/80), Krystyna Bełkowska (1973-1978, zeszyty: 9-28, dodatek do $\mathrm{nr}$ 3/73-2/78), Barbara Michalczyk (1978-1986, zeszyty 29/30-59, dodatek do nr 3-4/78-3/86), Wanda Sadurska (1982-1983, zeszyty 45-49, dodatek do nr 3-4/82-34/83), Izabela Lenard (zeszyt 60, dodatek do numeru 1/87), następnie pracę podjęła Halina Dziewanowska (od nr 61, dodatek do numeru 2/87), która pracowała nieprzerwanie nad przygotowaniem Bibliografii aż do ostatniego - wydanego w 2007 r. - numeru 129 (dodatek do nr 2/2007 „Kwartalnika”).

7 Polska Bibliografia Naukoznawstwa i Technoznawstwa ukazywała się od 1966 do 2002 r. Pierwsze dwa tomy ukazały się pod nazwą Polska Bibliografia Naukoznawstwa i Ruchu Naukowego, następne numery jako Polska Bibliografia Naukoznawstwa, kolejne tomy to Polska Bibliografia Naukoznawstwa i Technoznawstwa. Bibliografia obejmowała piśmiennictwo od 1963 do $2000 \mathrm{r}$.

8 Biblioteka została zlikwidowana przez Prezydium PAN w dniu 31 marca 2005 r.; około 176000 jednostek należących do Biblioteki PAN w Warszawie przejęła Biblioteka Gdańska, bgpan.gda.pl/o-bibliotece/zbiory/ [dostęp 06.10.2020]. Dokumentacja służbowa została przekazana do Archiwum PAN w Warszawie, prace naukowe i dokumentacyjno-bibliograficzne w zakresie naukoznawstwa, historii i upowszechniania nauki, a także badań nad przyszłością (prognozologia) zostały przerwane. Zob. B. Sordylowa, Moje związki z informacją naukową, „Biuletyn Biblioteki Jagiellońskiej” t. 65, 2015, s. 106.

9 M. Dembowska, Przedmowa, [w:] Polska Bibliografia Naukoznawstwa i Technoznawstwa za lata 1971-1973, t. 5, Wrocław 1973, s. 5.

10 Bibliografia bieżąca historii nauki i techniki. Zeszyt 2. Dodatek do numeru 4/1971 „Kwartalnika Historii Nauki i Techniki”, „Kwartalnik Historii Nauki i Techniki” t. 16, 1971, nr 4. 
Bibliografia bieżąca historii nauki i techniki miała węższy zakres tematyczny niż wspomniana wyżej Bibliografia Naukoznawstwa. Obejmowała szeroko pojętą historię nauki i techniki, uwzględniając zarówno prace o charakterze ogólnym, jak i historię badań dotyczącą poszczególnych dyscyplin naukowych, a także prace o charakterze opisowym, faktograficznym, jak np. sprawozdania z kongresów, zjazdów, konferencji (tematycznie związanych z zagadnieniami z historii nauki). Znaleźć w niej można również sprawozdania z działalności instytucji naukowych, obejmujące okresy co najmniej pięcioletnie. Bibliografia rejestrowała również prace bio-bibliograficzne dotyczące uczonych. Pod względem formalnym obejmowała druki zwarte, artykuły w wydawnictwach zbiorowych oraz artykuły i recenzje publikowane w czasopismach (począwszy od miesięcznika). W zasadzie Bibliografia miała nie publikować informacji o pracach popularno-naukowych ani artykułów z tygodników społeczno-kulturalnych czy dzienników. Zdarzały się jednak wyjątki od tej zasady, dotyczące publikacji które prezentowały poważną informację naukową (np. wypowiedzi naukowców publikowane w tygodnikach lub dziennikach). Bibliografia rejestrowała zasadniczo piśmiennictwo polskie, sporadycznie - polonica (publikacje zagraniczne dotyczące nauki polskiej lub dotyczące powszechnej historii nauki, których autorami byli Polacy). Podtytuł Bibliografii podawał każdorazowo okres, w którym zostały opublikowane materiały wchodzące do zeszytu. Uwzględniano również materiały spóźnione lub pominięte z różnych przyczyn w poprzednich numerach.

Bibliografia podzielona została na następujące stałe działy:

I. Zagadnienia ogólne historii nauki i techniki;

II. Historia nauk społecznych;

III. Historia nauk biologicznych i rolniczo-leśnych;

IV. Historia nauk medycznych;

V. Historia nauk matematyczno-fizyczno-chemicznych;

VI. Historia nauk o Ziemi;

VII. Historia nauk technicznych i techniki.

Układ ten odpowiadał schematowi organizacyjnemu Polskiej Akademii Nauk, jak również zespołom badawczym Zakładu Historii Nauki i Techniki. Taki podział ułatwiał również sprawne wyszukiwanie publikacji z konkretnej dziedziny nauki.

W obrębie działów pozycje bibliograficzne uszeregowane były alfabetycznie (według nazwisk autorów lub tytułów prac naukowych). Miały one miały numerację ciągłą w obrębie każdego roku. Metoda opisu została dostosowana do polskich norm bibliograficznych. Opis bibliograficznych pozycji składał się z następujących elementów: autor, tytuł, rok ukazania się danej pozycji (tytuł i numer czasopisma), objętość, tj. liczba stron, dodatki graficzne (portrety, fotografie, mapy, rysunki), informacje o streszczeniach obcojęzycznych, adnotacje, przeważnie typu wyjaśniającego. Jeżeli opisywana pozycja była recenzowana, podawano również autora recenzji lub notatki, tytuł recenzji (jeżeli był), miejsce jej publikacji, rok, numer i strony. Poszczególne pozycje bibliograficzne były numerowane w obrębie roku. Jak podaje Indeks do Bibliografii Bieżącej Historii Nauki i Techniki, w ciągu pierwszych 10 lat wydawania bibliografii (do zeszytu 40, dodatku do nr 2/1981) znalazło się w niej 14287 pozycji bibliograficznych"11. Od zeszytu 41 (dodatek do nr 3-4/1981) 
do zeszytu 79 (dodatek do nr 4/91) - 16650 pozycji. Od 1992 r. aż do końca wydawania Bibliografii numeracja była już ciągła. Ostatnia pozycja ma numer 15985 . Łącznie w ciągu 36 lat ukazywania się publikacji zawarto w niej aż 46922 pozycje z szeroko pojętej dziedziny historii nauki. Mniejsza liczba wykazanych publikacji w ostatnim piętnastoleciu była najprawdopodobniej spowodowana zmniejszeniem liczby osób nad nią pracujących.

W nielicznych numerach można było znaleźć również informację o maszynopisach złożonych w Archiwum Zakładu Historii Nauki i Techniki. Pierwsze cztery zeszyty zawierały także wykaz czasopism i ich skrótów. Jednak od numeru 5 (dodatek do numeru 3/1972) zespół redakcyjny zrezygnował z podawania wykazu uwzględnionych czasopism, ponieważ powodowało to wiele nieporozumień, na przykład zarzut, że nie wszystkie czasopisma, które mogą zawierać materiały z dziedziny historii nauki, są przeglądane. Postanowiono natomiast dołączać raz w roku wykaz przejrzanych czasopism, tak z wynikiem pozytywnym, jak i negatywnym. Zamierzenie to nie zostało jednak zrealizowane przy żadnym numerze Bibliografii. Tak samo nie został zrealizowany zamiar publikowania w okresach pięcioletnich indeksu rzeczowego. Ukazał się tylko jeden tom indeksów za lata 1971-1980, zawierający Indeks autorów i wspótpracowników i Indeks przedmiotowy osób i instytucji12.

Jak wspomniano, pierwszy zeszyt Bibliografii bieżącej historii nauki i techniki ukazał się jako wkładka do nr 3/1971 „Kwartalnika Historii Nauki i Techniki”, a ponadto został rozesłany do około stu osób (wraz z zeszytem 2 i ankietą), zajmujących się historią nauki i techniki, które zapytywano, czy są zainteresowane nowym wydawnictwem i czy jest ono użyteczne w ich pracy. Na ankietę odpowiedziało około pięćdziesiąt osób, które życzliwie przyjęły inicjatywę Redakcji „Kwartalnika” i wypowiedziały się zdecydowanie za kontynuacją tego - jedynego z tego zakresu w Polsce - wydawnictwa. Korespondencja ta podsunęła redakcji „Kwartalnika” i autorkom cenne sugestie, dotyczące zakresu i zasięgu Bibliografii, które wpłynęły na ostateczny kształt publikacji.

Oczywiście przygotowanie takiej publikacji, w tak krótkim (kwartalnym) terminie, byłoby ogromnie trudnym zadaniem, gdyby nie zbiory Biblioteki Instytutu Historii Nauki PAN, a także jej pracownicy.

Biblioteka ta powstała w 1958 r. Została utworzona jako 8 komórka - Dział Dokumentacji i Biblioteka - przy powołanym 1 lipca 1958 r. Uchwałą Prezydium PAN (nr 15/58 z 22 kwietnia 1958 r.) Zakładzie Historii Nauki i Techniki PAN ${ }^{13}$. W czasie ponad sześćdziesięcioletniej działalności zgromadziła duży potencjał materialny - specjalistyczne zbiory naukowe (wydawnictwa zwarte i czasopisma), które stanowią cenny dorobek, którym dysponować może nauka polska. Profil zbiorów obejmuje: historię, historię nauk społecznych i humanistycznych, historię oświaty i wychowania, historię medycyny, historię nauk ścisłych i technicznych, oraz historię nauk o Ziemi. Obecnie księgozbiór liczy ok. 18 tys. woluminów książek i 80 tytułów czasopism (np. „Annals of Science”, „Archive for History of Exact Sciences”, „Historia Mathematica”, "History and Philosophy of Life Sciences", "History of Education”, "Isis", „Journal for the History of Astronomy”, „Science in Context"). Biblioteka gromadzi też zbiory specjalne: stare druki, mikrofilmy, fotokopie i rękopisy.

13 W. Sygocki, Instytut Historii Nauki PAN w latach 1953-2003. Kalendarium, [w:] Instytut Historii Nauki Polskiej Akademii Nauk w latach 1953-2003, s. 20-21. 
Pierwszą opiekunką zbiorów była Beata Szczepańska14, która stworzyła zasadniczy zrąb obecnego, specjalistycznego księgozbioru Zakładu. Prof. Irena Stasiewicz-Jasiukowa, wieloletni pracownik i kierownik Zakładu Nauk Społecznych Instytutu, w swoim wspomnieniu o Szczepańskiej przypomniała, że Biblioteka Instytutu Historii Nauki i Techniki (mieszcząca się obecnie w Pałacu Staszica w Warszawie) rozpoczęła swoją działalność w 1958 r. w małym pokoju na 24 piętrze Pałacu Kultury i Nauki. Dysponowała jedną szafą i biurkiem. Pokój ten był nie tylko pomieszczeniem bibliotecznym, lecz również pełnili w nim dyżury uwcześni asystenci i doktoranci Instytutu. Po 13 latach pracy Szczepańskiej (w 1969 r. - gdy odchodziła na emeryturę) biblioteka liczyła już ok. 7000 tytułów książek i kilkadziesiąt tytułów czasopism. 50 lat temu, w odmiennych warunkach społeczno-gospodarczych, gromadzenie specjalistycznych książek było zupełnie inne niż dziś. Tylko dzięki niezwykłej umiejętności ówczesnej kierowniczki Biblioteki i jej niebywałym zdolnościom nawiązywania kontaktów z antykwariuszami z całej Polski do zbiorów udało się wprowadzić niezmiernie wartościowy księgozbiór dziedziny historii nauki i techniki. Oprócz tego Biblioteka gromadziła wręcz nieosiągalne w tamtych czasach - dzięki systematycznej wymianie z ośrodkami zagranicznymi - czasopisma obcojęzyczne ${ }^{15}$.

Jak wspominał z kolei Róziewicz ${ }^{16}$, Szczepańska zorganizowała w Warszawie (Pałac Kazimierzowski na Uniwersytecie Warszawskim) i Krakowie (Biblioteka Jagiellońska) wystawę książek z okazji XI Międzynarodowego Kongresu Historii Nauki ${ }^{17}$. Na wystawach pokazano ponad 1100 woluminów najbardziej znaczących publikacji z zakresu historii nauki z kilkudziesięciu krajów świata, co wzbudziło ogromny podziw uczestników Kongresu. Do pomocy w organizacji wystawy Szczepańska miała tylko jedną osobę, wspomnianego wyżej autora artykułu, nieżyjącego już profesora (wówczas magistra) Jerzego Róziewicza (od 1966 r. aż do śmierci związanego z Instytutem Historii Nauki PAN). Udało się im pozyskać publikacje z takich krajów jak: Belgia, Czechosłowacja, Holandia, Japonia, Niemcy (RFN), Stany Zjednoczone, Wielka Brytania, Włochy, Związek Radziecki. Ponadto Instytut Brytyjski w Warszawie z okazji Kongresu podarował Zakładowi 260 woluminów książek ${ }^{18}$. Wszystkie dary przeszły na własność Biblioteki Zakładu.

\section{Zakończenie - reaktywacja bieżącej bibliografii historii nauki}

Obecnie Dyrekcja Instytutu Historii Nauki PAN postanowiła reaktywować wydawanie bieżącej bibliografii historii nauki. Jak wspomniano, do połowy 2007 r. ukazało się 129 zeszytów bibliografii. Jednak w latach 2008-2017 bibliografia taka nie ukazywała się. Ta luka również będzie uzupełniana. Pozwoli na to utworzenie Internetowej Bibliografii Historii

14 Beata Szczepańska rozpoczęła pracę w Zakładzie 1 VIII 1956 r

15 I. Stasiewicz-Jasiukowa, Wspomnienie o Beacie Szczepańskiej (1906-1997), „Kwartalnik Historii Nauki i Techniki" t. 42, 1997, nr 3-4, s. 159-162.

16 J. Róziewicz, Moje pierwsze trzy lata w Zakładzie Historii Nauki i Techniki PAN (1967-1967), [w:] Instytut Historii Nauki Polskiej Akademii Nauk w latach 1953-2003, s. 353-365.

17 XI Międzynarodowy Kongres Historii Nauki, 24-32 VIII 1965 r., Warszawa - Kielce - Kraków. Organizatorem i gospodarzem Kongresu był Komitet Historii Nauki i Techniki PAN.

18 J. Róziewicz, op. cit. 
Nauki (na razie plan ten jest ciągle na etapie koncepcji z powodu pandemii i związanych z nią kłopotów z bezpośrednim dostępem do książek w bibliotekach).

Prace nad przygotowaniem wersji drukowanej zlecono autorce artykułu. Bibliografia ma ukazywać się raz w roku (za rok ubiegły). Pierwszy numer za 2018 r. ukazał się w półroczniku „Analecta. Studia i Materiały z Dziejów Nauki"19. Zakres i zasięg bibliografii ma być taki sam, jak w opisanym powyżej dodatku do „Kwartalnika”: ma obejmować prace zamieszczone w książkach i czasopismach naukowych, a także publikowanych na stronach internetowych. Niektóre z nich są stosunkowo łatwe do zidentyfikowania np. w katalogach wydawnictw lub w Internecie. Głównymi bazami danych, pomagającymi wyszukać i zapoznać się z publikacjami, spełniającymi kryteria doboru dla historii nauki są przede wszystkim BazHum i BazTech. Jest jednak znaczna liczba książek i artykułów ogłoszonych w różnych, zwłaszcza regionalnych placówkach kulturalnych (m.in. muzeach, stowarzyszeniach, towarzystwach naukowych), których egzemplarz obowiązkowy nie trafia do najważniejszych bibliotek krajowych. Nakład publikacji tego typu tylko niekiedy przekracza 100 egzemplarzy. Jest jeszcze jedna grupa publikacji - czasem bardzo ważnych - sponsorowanych przez różne resorty oraz samorządy. Rozdawane przy okazji różnych konferencji przechodzą niepostrzeżenie i trafiają po latach do obiegu antykwarycznego.

Wspomniane niskie nakłady publikacji, ich lokalny zasięg, a także brak profesjonalnego obiegu księgarnianego (księgarnie praktycznie nie interesują się publikacjami naukowymi) powodują, że uczeni często z opóźnieniem dowiadują o publikacjach z interesującej ich dziedziny, które ukazują się w innych ośrodkach. Bibliografia historii nauki ma ambicje temu zaradzić, do czego przyczyni się niewątpliwie planowane przez Dyrekcję Instytutu Historii Nauki PAN umieszczenie takiej bazy danych w niedługim czasie w Internecie.

\section{Bibliografia}

Bibliografia bieżąca historii nauki i techniki. Indeksy za lata 1971-1980. Indeks autorów i współpracowników. Indeks przedmiotowy osób i instytucji, zestawiły M. Jedlińska, I. Lenart, B. Michalczyk, red. M. Kinowska, J. Róziewicz, Warszawa 1983.

Bibliografia bieżąca historii nauki i techniki. Zeszyt 1. Dodatek do numeru 3/1971 „Kwartalnika Historii Nauki i Techniki”, "Kwartalnik Historii Nauki i Techniki” t. 16, 1971, nr 3.

Bibliografia bieżąca historii nauki i techniki. Zeszyt 2. Dodatek do numeru 4/1971 „Kwartalnika Historii Nauki i Techniki”, „Kwartalnik Historii Nauki i Techniki” t. 16, 1971, nr 4.

Dembowska M., Przedmowa, [w:] Polska bibliografia naukoznawstwa i technoznawstwa za lata 1971-1973, t. 5, Wrocław 1973, s. 5-7.

Instytut Historii Nauki Polskiej Akademii Nauk w latach 1953-2003, red. K. Bartnicka, Warszawa 2004.

Kozłowska D., Bibliografia historii nauki polskiej za 2018 rok (wybór), „Analecta. Studia i Materiały z Dziejów Nauki" t. 28, 2019, nr 2, s. 179-224.

19 D. Kozłowska, Bibliografia historii nauki polskiej za 2018 rok (wybór), „Analecta. Studia i Materiały z Dziejów Nauki" t. 28, 2019, nr 2, s. 179-224. 
Sordylowa B., Moje związki z informacją naukową, "Biuletyn Biblioteki Jagiellońskiej” t. 65, 2015, s. 99-112.

Stasiewicz-Jasiukowa I., Wspomnienie o Beacie Szczepańskiej (1906-1997), „Kwartalnik Historii Nauki i Techniki" t. 42, 1997, nr 3-4, s. 159-162.

Voisé W., O zadaniach i metodzie historii nauk społecznych, „Kwartalnik Historii Nauki i Techniki" t. 3, 1958, nr 1, s. 9-10.

mgr Dorota Kozłowska pracuje w Instytucie Historii Nauki im. L. i A. Birkenmajerów PAN (Pracownia Naukoznawstwa i Dział Wydawniczy). Od 2007 r. sekretarz Zespołu Historii Kartografii. Od 2018 r. prowadzi prace nad reaktywowaniem Bibliografii Historii Nauki (również wersji Internetowej). Zainteresowania: historia nauki, historia nauk przyrodniczych.

e-mail: dorotapeczlewicz@gmail.com

Data zgłoszenia artykułu: 19 października 2020

Data przyjęcia do druku: 26 października 2020 